University of Nebraska - Lincoln

DigitalCommons@University of Nebraska - Lincoln

Agronomy \& Horticulture -- Faculty Publications

Agronomy and Horticulture Department

2009

Evaluation of the waxy endosperm trait in proso millet (Panicum miliaceum)

Robert A. Graybosch

University of Nebraska-Lincoln, bob.graybosch@ars.usda.gov

D. D. Baltensperger

University of Nebraska-Lincoln, dbaltensperger@tamu.edu

Follow this and additional works at: https://digitalcommons.unl.edu/agronomyfacpub

Part of the Plant Sciences Commons

Graybosch, Robert A. and Baltensperger, D. D., "Evaluation of the waxy endosperm trait in proso millet (Panicum miliaceum)" (2009). Agronomy \& Horticulture -- Faculty Publications. 367.

https://digitalcommons.unl.edu/agronomyfacpub/367

This Article is brought to you for free and open access by the Agronomy and Horticulture Department at DigitalCommons@University of Nebraska - Lincoln. It has been accepted for inclusion in Agronomy \& Horticulture -Faculty Publications by an authorized administrator of DigitalCommons@University of Nebraska - Lincoln. 


\title{
Evaluation of the waxy endosperm trait in proso millet (Panicum miliaceum)*
}

\author{
R. A. Graybosch ${ }^{1}$ and D. D. Baltensperger ${ }^{2,3}$ \\ ${ }^{1}$ USDA-ARS, Department of Agronomy \& Horticulture, University of Nebraska, Lincoln, NE 68583, \\ E-mail: Bob.Graybosch@ARS.USDA.Gov; ${ }^{2}$ Department of Agronomy \& Horticulture, University of Nebraska, Lincoln, NE \\ 68583, USA; ${ }^{3}$ Present address: Department of Soil and Crop Sciences, Texas A\&M University, College Station, TX 77843, USA \\ With 1 figure and 3 tables
}

Received April 30, 2007/Accepted February 8, 2008

Communicated by R. Tuberosa

\begin{abstract}
The entire USDA-ARS maintained collection of 650 accessions of proso millet (Panicum miliaceum L.) was evaluated for the presence of accessions with waxy (amylose-free) endosperm starch. Six accessions, five of which derived from mainland China, were identified. Segregation ratios for waxy endosperm were evaluated in $F_{2}$ and $F_{3}$ populations derived from crosses between two waxy accessions, PI 436625 (Lung Shu 16) and PI 436626 (Lung Shu 18), and several wildtype accessions. The waxy trait was found to be under the control of duplicate recessive alleles at two loci, herein designated $w x-1$ and $w x-2$. Wild-type alleles at these loci were designated $W x-1$ and $W x-2$. Iodinebinding revealed a mean grain-starch amylose concentration of $3.5 \%$ in waxy lines and $25.3 \%$ in wild-type proso. Expression of the granulebound starch synthase (waxy protein) in waxy lines was reduced to approximately one-tenth that of wild-type accessions. The waxy accessions identified now are available for the introgression of this trait into breeding lines adapted to the Great Plains of North America.
\end{abstract}

Key words: Panicum miliaceum — proso millet — starch amylose — amylopectin — waxy — inheritance — granulebound starch synthase

Proso millet, or proso (Panicum miliaceum L.) is one of mankind's most ancient cultivated crops. Evidence of its cultivation exists in China from as long ago as 5000 BC; from there it spread to India and across the Eurasian steppes, reaching eastern Europe approximately 4000 years ago (Lágler et al. 2005). Proso is a relatively short-season crop, with very limited water requirements. Hence, it is ideally suited for cultivation in areas with hot, dry and short summer seasons (Baltensperger 2002). In North America, proso is most commonly produced in the drier regions of the western Great Plains, where it is often employed as a rotational crop with winter wheat. Most current US production occurs in the states of Kansas, Nebraska, Colorado, Wyoming and North and South Dakota. At present, the bulk of the US proso crop is utilized in the wild bird seed market. However, proso millet products have found use in the diets of patients with coeliac disease. Because of the protein composition and the contents of some specific components with health benefits, proso grains

*Joint contribution of the United States Department of Agriculture, Agricultural Research Service (USDA-ARS) and the Department of Agronomy and Horticulture, University of Nebraska-Lincoln, supported by funds provided through USDA-ARS. Mention of firm names or trade products does not imply that they are endorsed or recommended by the USDA or the University of Nebraska over other firms or products not mentioned. can be the basis for the development of new foods (Kalinova 2007).

The entire current US proso crop is in the form of types with wild-type starch (starch is composed of a mixture of amylose and amylopectin). Waxy forms (amylose-free starch) exist, and have been known to science since at least 1885 (Dafert, 1885; cited by Hixon and Brimhall 1968). Human consumption of proso occurs across much of Asia, and is increasing in North America. In many such markets, waxy types, because of their glutinous nature and greater properties of adhesion after cooking, are preferred. Waxy cereals produce endosperm starch devoid of amylose, generally as a consequence of mutations in the $w x$ loci, the genes responsible for the production of the enzyme granule-bound starch synthase (GBSS; Smith et al. 1997). In the late 1990s, we established a research programme aimed at the development of waxy proso types suitable for cultivation in North America. Previous evaluation of waxy types from China had found them to be too late in maturity for successful seed harvest in Great Plains environments.

Despite its long history in cultivation, proso has received scant genetic characterization (Zeller 2000). Proso generally is described (Zeller 2000) as an allotetraploid, in which $2 \mathrm{n}=4 \mathrm{x}=36$. Forms with 72 chromosomes have also been noted (Wanous 1990). There has been some recent work characterizing DNA polymorphisms in proso (Lágler et al. 2005). Little is known, however, of the inheritance of qualitative traits. The goals of the present investigation were to: (i) identify waxy types of proso from the USDA-ARS collection maintained at the North Central Regional PI Station, Ames, Iowa; (ii) evaluate the inheritance of the trait after matings with wild-type proso and (iii) examine the effects of waxy mutant alleles on starch amylose content and GBSS expression.

\section{Materials and Methods}

Six hundred and fifty accessions of proso obtained from the USDAARS North Central Regional PI Station, Ames, IA were analysed. Forty-eight seeds of each accession were placed in Costar 48-well microplates (Corning Inc., Corning, NY, USA) and coarsely crushed with a HyPure Seed Crusher (Perkin-Elmer Wallac Inc., Norton, $\mathrm{OH}, \mathrm{USA})$. Iodine stain solution was prepared as follows: stock solution $=5 \mathrm{~g}$ KI plus $0.5 \mathrm{~g} \mathrm{I}_{2}$ per $250 \mathrm{ml} \mathrm{H}_{2} \mathrm{O}$; working solution $=50 \mathrm{ml}$ stock solution plus $950 \mathrm{ml} \mathrm{H}_{2} \mathrm{O}$. The working solution was used until the colour began to fade, and then fresh solution was prepared. Fifty microlitres of iodine stain solution were added to 
each sample and the colour reaction scored after 1 min. Seeds staining dark blue to black were scored as wild type, while waxy seeds were noted by their pinkish or amber to reddish-brown colour. A dissecting microscope (40× magnification) was used to facilitate evaluations.

Waxy accessions (see Results) PI 436625 and PI 436626, along with the wild-type accessions 'Early-bird', 'Huntsman', 'Sunrise', PI 170597, PI 177484, PI 250979 and PI 346940 were sown in a growth chamber, and cultured under a diurnal temperature regime of $27^{\circ} \mathrm{C}$ day $/ 16^{\circ} \mathrm{C}$ night. Day-length initially was set at $18 \mathrm{~h}$, and reduced to $12 \mathrm{~h}$ after 4 weeks of vegetative growth to induce flowering. Three plants were seeded per pot, and three pots seeded per accession. Eight inch diameter pots filled with Sunshine soil mixture \#1 (Fisons Horticulture Co., Mississauga, MB, USA) were used. Artificial matings were obtained between waxy and wild-type lines via the method of Nelson (1984). $F_{1}$ plants (minimum of three per cross) were grown under identical conditions, and $F_{2}$ seed were scored as waxy/wild type as described above. $\mathrm{F}_{2}$ populations were sown in single-row $4.5 \mathrm{~m}$ plots at the University of Nebraska Panhandle Research Station $\left(41.58^{\circ} \mathrm{N}\right.$ $103.45^{\circ} \mathrm{W}$, elevation $=1195 \mathrm{~m}$ ) in Scottsbluff, NE in 2000. Soil type was a Tripp very fine sandy loam (Aridic Haplustolls) with a $1.0 \%$ organic matter content and a $\mathrm{pH}$ of 8.1. Plots were seeded on 1 June 2000, and harvested by hand on 7 September 2000. Average air temperature during this time period was $22.1^{\circ} \mathrm{C}$, and $12.5 \mathrm{~cm}$ precipitation was received during the growing season. Irrigation was used to supplement moisture received via rainfall.

From each $F_{2}$ population verified as segregating, single plant selections were made by harvesting panicles separately. $F_{2}$ genotypes then were determined by segregation ratios using $\mathrm{F}_{3}$ seed. Chi-squared (Steel and Torrie 1980) analysis was used to test for goodness-of-fit to $3: 1$ and $15: 1$ ratios. A minimum of $96 \mathrm{~F}_{3}$ seeds were evaluated from each segregating $F_{2}$ family. Microsoft Office Excel ${ }^{\circledR}$ was used for all computations. An average of $30 \mathrm{~F}_{2}$-derived families were evaluated per cross; however, late maturity under Nebraska field conditions of the progeny of some crosses allowed successful field harvest of fewer lines. Late maturing lines failed to complete typical plant senescence before the first killing frost.

Grain starch amylose concentrations were determined as per Knutson and Grove (1994). Thirty-six true breeding wild-type lines, and an equal number of true breeding waxy types, were selected at random from amongst the $F_{2}$ populations. Grain was ground in a coffee grinder. A flour sample from the wheat (Triticum aestivum L.) cultivar 'Scout 66' with a starch amylose concentration of $27.6 \%$ was used as a laboratory control. Grain starch amylose assays were determined in duplicate for each line, and mean concentrations of amylose for each genotypic class, waxy and wild type, were determined.

Starch granule proteins, specifically the GBSS, were evaluated via sodium dodecyl sulphate polyacrylamide gel electrophoresis (SDSPAGE). Starch was extracted and purified from the wild-type proso millets PI 170597, 'Sunrise' and 'Sunup', and from the waxy accessions PI 436623, PI 436625 and PI 436626. For quantitative evaluations of GBSS concentrations, starch was purified from the wild-type cultivar
'Huntsman' and 10 each true-breeding wild type and waxy lines selected at random from the $F_{2}$ populations. Starch was purified from either ground grain samples or single seeds via extraction with a buffer containing $60 \mathrm{~mm}$ Tris- $\mathrm{HCl}(\mathrm{pH}$ 6.8), 3\% (w/v) SDS, 3\% (v/v) B-mercaptoethanol and $10 \%(\mathrm{v} / \mathrm{v})$ glycerol, followed by two washes with acetone and two washes with water (Graybosch et al. 1998). Proteins were extracted by boiling $10 \mathrm{mg}$ purified starch samples in an extraction buffer composed of $2 \%$ SDS (w/v), $10 \%(\mathrm{v} / \mathrm{v})$ glycerol, $0.06 \mathrm{~m}$ Tris- $\mathrm{HCl}(\mathrm{pH} 8.8), 0.04 \mathrm{~m}$ dithioerythritol and $2 \mathrm{~mm}$ ethylenediaminetetraacetic acid, and subsequently separated via SDS-PAGE (Graybosch et al. 1998). Starch-granule proteins of the wheat cultivar 'Scout 66' were included as controls. Gels were stained by agitation for $15 \mathrm{~h}$ in a solution of $18.8 \mathrm{~g} 85 \% \mathrm{H}_{3} \mathrm{PO}_{4}, 80 \mathrm{~g}$ ammonium sulphate and $0.8 \mathrm{~g}$ Coomassie Brilliant Blue G-250 per litre. The Coomassie Brilliant Blue G-250 was first dissolved in $200 \mathrm{ml}$ methanol, and then added to $800 \mathrm{ml} \mathrm{H}_{2} \mathrm{O}$ containing the additional ingredients. Gels were run in duplicate, stained overnight, and destained with two changes of distilled deionized $\mathrm{H}_{2} \mathrm{O}$. GBSS concentrations ( $\mu \mathrm{g} / \mathrm{mg}$ starch) were estimated by use of IMAGEJ software (Research Services Branch, National Institute of Mental Health, Bethesda, MD, USA), using a regression equation $\left(r^{2}=0.97\right)$ developed from separation and evaluation of known concentrations of bovine serum albumin (BSA). Mean values of 10 random selections from each class, waxy and wild type, were determined.

\section{Results}

Six waxy accessions were identified amongst the USDA-ARS proso germplasm collection. These were: PI 346946, originally obtained from the Vavilov Institute in Russia, and five Plant Introductions from China, PI 436622 (Lung Shu 5), PI 436623 (Lung Shu 7), PI 436624 (Lung Shu 14), PI 436625 (Lung Shu 16) and PI 436626 (Lung Shu 18). The 'Lung Shu' selections all were obtained by the USDA in 1979 from the Germplasm Research Institute in Beijing. No further information on their origin is available; however, the common designation 'Lung Shu' suggests that they were derived from a single breeding programme or location.

Crosses were obtained between two (PI 436625 and PI 436626) of the waxy accessions, and several wild-type lines (Table 1). $F_{2}$ segregation ratios from each cross (Table 1), and from the pooled observations of all crosses, did not significantly depart from a ratio of 15 wild-type : 1 waxy progeny. Chi-squared analysis (Table 1) of each cross, and of the pooled results, all showed a significant departure from an alternative hypothesized ratio of $3: 1$. The chi-squared test for homogeneity was significant (Table 1); this supports the hypothesis that the two classes, waxy and wild type, appear in equal proportions in each population. These ratios demonstrate the waxy trait was recessive, and that two independently inherited and dominant waxy loci exist within wild-type proso. These
Table 1: $F_{2}$ segregation ratios in progeny of matings between waxy (PI 436625 or PI 436626) and wildtype parents

\begin{tabular}{lrcccccc}
\hline Pedigree & $\begin{array}{c}\text { Number } \\
\text { tested }\end{array}$ & $\begin{array}{c}\text { Number } \\
\text { waxy }\end{array}$ & $\begin{array}{c}\text { Number } \\
\text { wild type }\end{array}$ & $\begin{array}{c}\chi^{2} \\
(3: 1)\end{array}$ & P-value & $\begin{array}{c}\chi^{2} \\
(15: 1)\end{array}$ & P-value \\
\hline Earlybird/PI 436626 & 256 & 20 & 236 & 40.33 & 0.005 & 1.07 & 0.30 \\
Huntsman/PI 436625 & 128 & 10 & 118 & 20.17 & 0.005 & 0.53 & 0.47 \\
PI 177484/PI 436625 & 128 & 8 & 120 & 24.00 & 0.005 & 0.00 & 1.00 \\
PI 250979/PI 436626 & 128 & 10 & 118 & 20.17 & 0.005 & 0.53 & 0.47 \\
PI 346940/PI 436626 & 128 & 13 & 115 & 15.04 & 0.005 & 3.33 & 0.07 \\
PI 436625/PI 170597 & 416 & 25 & 391 & 80.01 & 0.005 & 0.04 & 0.84 \\
P 436625/PI 346940 & 256 & 21 & 235 & 38.52 & 0.005 & 1.67 & 0.20 \\
PI 436626/PI 170597 & 96 & 6 & 90 & 18.00 & 0.005 & 0.00 & 1.00 \\
Sunrise/PI 436626 & 128 & 9 & 119 & 22.04 & 0.005 & 0.13 & 0.72 \\
Total & 1664 & 122 & 1542 & 277.0385 & 0.005 & 3.32 & 0.07 \\
Homogeneity $\chi^{2}(\mathrm{df}=8)$ & & & & & & 3.45 & 0.90 \\
\hline
\end{tabular}


Number of $F_{2}$-derived families fitting respective classes
Table 2: $F_{3}$ segregation ratios of $\mathrm{F}_{2}$-derived families from matings between waxy (PI 436625 or PI 436626) and wild-type parents

\begin{tabular}{lrrrrrrr}
\cline { 2 - 6 } Pedigree & Wild type & $15: 1$ & $3: 1$ & Waxy & Total & $\chi^{2}(9: 3: 3: 1)$ & P-value \\
\hline Earlybird/PI 436626 & 21 & 9 & 7 & 3 & 40 & 1.80 & 0.61 \\
Huntsman/PI 436625 & 20 & 3 & 4 & 2 & 29 & 8.18 & 0.04 \\
PI 177484/PI 436625 & 8 & 4 & 7 & 0 & 19 & 2.38 & 0.50 \\
PI 250979/PI 436626 & 21 & 15 & 8 & 1 & 45 & 3.44 & 0.33 \\
PI 346940/PI 436626 & 5 & 1 & 1 & 1 & 8 & 2.14 & 0.54 \\
PI 436625/PI 170597 & 26 & 14 & 12 & 2 & 54 & 0.98 & 0.80 \\
PI 436625/PI 346940 & 14 & 10 & 10 & 3 & 37 & 0.62 & 0.89 \\
PI 436626/PI 170597 & 20 & 6 & 7 & 1 & 34 & 3.36 & 0.34 \\
Sunrise/PI 436626 & 21 & 8 & 8 & 3 & 40 & 1.60 & 0.66 \\
Total & 156 & 70 & 64 & 16 & 306 & 6.76 & 0.08 \\
\hline
\end{tabular}

Table 3: Biochemical characteristics of starches from wild-type and waxy proso millets

\begin{tabular}{|c|c|c|c|c|c|}
\hline Genotype & $\mathrm{n}$ & Mean & SD & Minimum & Maximum \\
\hline \multicolumn{6}{|c|}{ Amylose content $(\%)$} \\
\hline Wild type & 36 & 25.3 & 3.2 & 18.8 & 32.2 \\
\hline Waxy & 36 & 3.5 & 1.0 & 1.3 & 5.1 \\
\hline \multicolumn{6}{|c|}{ Waxy protein concentration ( $\mu \mathrm{g} / \mathrm{mg}$ starch) } \\
\hline Wild type & 36 & 36.9 & 16.5 & 11.1 & 60.5 \\
\hline Waxy & 36 & 3.9 & 5.6 & 1.1 & 19.4 \\
\hline
\end{tabular}

loci are herein designated $W x-1$ and $W x-2$; recessive alleles are designated $w x-1$ and $w x-2$.

Duplicate factor inheritance of the recessive waxy trait was confirmed by $\mathrm{F}_{2}$ genotypes inferred from $\mathrm{F}_{3}$ segregation ratios (Table 2). Four expected $F_{2}$ genotypes were observed, namely, true-breeding wild-type, true-breeding waxy, segregating (3:1, wild type : waxy) and segregating (15:1, wild type : waxy). Within all crosses save one, and in the pooled analysis (Table 2) these genotypes were observed in the expected ratio of $9: 3: 3: 1$. In the cross between 'Huntsman' and PI 436625 , there was a deficiency of wild-type families observed.

Mean grain-starch amylose concentration of wild-type proso was $25.3 \%$, that of waxy lines was $3.5 \%$, with an observed range of $1.3-5.1 \%$ (Table 3 ). Wheat cultivars produce $1-3$ isoforms of GBSS, which migrate at apparent molecular masses of 59-61 kDa (Yamamori et al. 1992). The GBSS of wild-type proso millet was identified (Fig. 1) as a prominent protein of slightly smaller molecular mass than the wheat GBSS. While genetic studies (above) revealed duplicate $W x$ loci, we were unable to resolve two isoforms with the electrophoretic system employed. Starch granules of waxy proso also revealed a band co-migrating with wild-type GBSS, but present at a markedly reduced concentration (Fig. 1). Using known concentrations of BSA as a standard, mean GBSS concentration (Table 3) of wild-type lines was estimated as $36.9 \mu \mathrm{g} / \mathrm{mg}$ starch, nearly 10 times that of waxy lines $(3.9 \mu \mathrm{g} / \mathrm{mg}$ starch). Evaluation of starch purified from single seeds (not shown) demonstrated identical results, so contamination of waxy samples by trace amounts of wild-type grain during harvest or grinding operations, may be discounted.

\section{Discussion}

Duplicate factor inheritance of recessive traits is commonly observed in polyploid plants such as soybean (Glycine max L.)

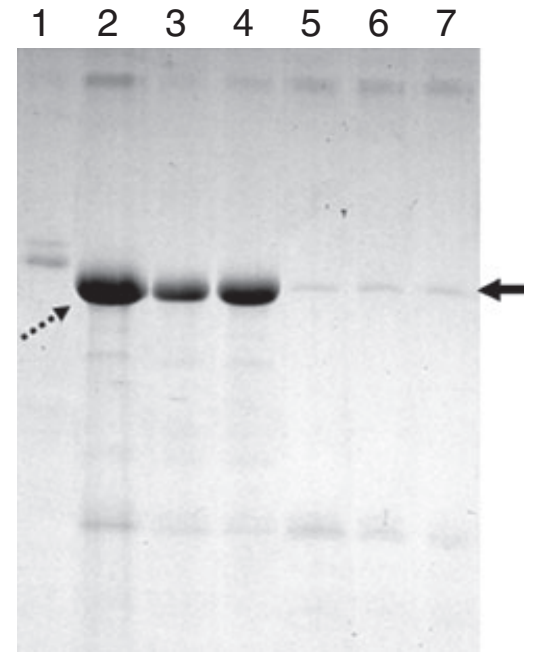

Fig. 1: Sodium dodecyl sulphate polyacrylamide gel electrophoresis separation of starch granule proteins from wheat cultivar 'Scout 66' (lane 1), three wild-type proso millets wild-type PI 170597, 'Sunrise' and 'Sunup' (lanes 2-4 respectively) and from the waxy accessions PI 436623, PI 436625 and PI 436626 (lanes 5-7, respectively). Starch was purified from bulked samples of several grains. Dashed arrow indicates wild-type granule-bound starch synthase (GBSS); solid arrow indicates diminished GBSS produced by waxy lines

that have undergone 'diploidization' (Lee et al. 1999). Proso millet has been described as an allotetraploid (Zeller 2000), where $2 n=4 \times=36$. Thus, the confirmation of the duplicate nature of the waxy loci in this species is hardly unexpected. Proso is facultatively heterogamous. It is largely self-pollinated; however, at higher temperatures $\left(>24^{\circ} \mathrm{C}\right)$ florets open and cross-pollination is possible. Outcrossing frequencies of up to $10 \%$ have been reported (Baltensperger and Cai 2004). Waxy forms of proso most likely arose in a stepwise manner, with independent mutations arising in different backgrounds to produce single null lines, followed by outcrossing between types resulting in the presence of double mutant waxy lines. Waxy forms of proso may then have been perpetuated by early subsistence farmers, perhaps as their glutinous texture after cooking provided some preferred mouth-feel, or aided in the eating process. Waxy proso millet evidently occurs widespread across Asia (Kimata and Negishi 2002). In other polyploid crops, such as wheat, lines carrying mutations at one or more of multiple GBSS-encoding loci are common (Yamamori et al. 1992, Graybosch et al. 1998). 
Wild-type starch amylose concentration $(25.3 \%)$ recorded herein is similar to that of previous reports for proso millet (Zeller 2000) and for cereals in general (Stoddard 2004). Trace amounts of amylose were detected in the starch of waxy proso. This may, however, merely reflect the known ability of amylopectin (waxy starches generally are assumed to be $100 \%$ amylopectin) to bind $1 \%$ (by weight) iodine, as opposed to the $20 \%$ binding by amylose (Stoddard 2004). The iodinebinding assay employed herein typically demonstrates a low level of iodine binding by amylopectin (Knutson and Grove 1994). A low level of GBSS activity might also occur in waxy proso lines. Trace amounts of GBSS were detected by SDSPAGE. A similar observation was reported in quinoa (Chenopodium quinoa Willd.) where 'waxy' types with both trace levels of GBSS production and activity were found in lines with 3.5-7.5\% starch amylose (Lindeboom et al. 2005). A similar low level of activity, with a subsequent low level of amylose production, may not be ruled out in proso.

The nature of the mutations at the $W x$ loci of proso is unknown. Most likely, one mutant allele produces no GBSS, while the second allele produces the trace amounts observed. Whether this form retains enzymatic activity remains to be demonstrated. Waxy mutants of wheat (Keeling et al. 2000), sorghum (Pedersen et al. 2005) and maize (Han et al. 2002) are known, however, in which GBSS is produced, but retains no enzymatic activity. Waxy proso may be of a similar nature, with the low levels of 'amylose' merely being a reflection of amylopectin binding of iodine.

Waxy proso accessions maintained by the USDA-ARS matured too late for successful cultivation in western Nebraska and other Great Plains environments. Subsequent to matings with adapted types, waxy proso with agronomic properties necessary for Great Plains production systems have been developed (Heyduck et al. 2008). Selected lines with grain yields equivalent to that of current proso cultivars, and double that of the original non-adapted waxy parents, have been identified (Heyduck et al. 2008). The western Great Plains of North America shortly will see the introduction of waxy proso as an alternative crop in the traditional wheat-fallow rotation systems.

\section{Acknowledgement}

Technical assistance of Lori Divis and Vern Hansen is gratefully acknowledged.

\section{References}

Baltensperger, D. D., 2002: Progress with proso, pearl and other millets. In: J. Janick, and A. Whipkey (eds), Trends in New Crops and New Uses, 100-103. ASHS Press, Alexandria, VA.

Baltensperger, D., and Y. Z. Cai, 2004: Minor millets. In: C. Wrigley, H. Corke, and C. E. Walker (eds), Encyclopedia of Grain Science, Vol. 2. 261-268. Elsevier Science, Amsterdam.

Graybosch, R. G., C. J. Peterson, L. E. Hansen, S. Rahman, A. Hill, and J. H. Skerritt, 1998: Identification and characterization of U.S. wheats carrying null alleles at the wx loci. Cereal Chem. 75, $162-165$.

Han, X. Z., O. H. Campanella, H. Guan, P. L. Keeling, and B. R. Hamaker, 2002: Influence of maize starch granule-associated protein on the rheological properties of starch pastes: Part I. Large deformation measurements of paste properties. Carbohydr. Polym., 49, 323-330.

Heyduck, R. F., D. D. Baltensperger, L. A. Nelson, and R. A. Graybosch, 2008: Assessing the stability of agronomic traits in waxy proso (Panicum miliaceum L.) in the Central Great Plains. Crop Sci., 48, 741-748.

Hixon, R. M., and R. Brimhall, 1968: Waxy cereals and red iodine starches. In: J. A. Radley (ed.) Starch and its Derivatives, 247-281. Chapman and Hall, Ltd, London, UK.

Kalinova, J., 2007: Nutritionally important components of proso millet (Panicum miliaceum L.). Food 1, 91-100.

Keeling, P. L., F. G. Dunlap, and M. Chang, 2000: Waxy Wheat Starch Type Having Waxy Proteins in Granule. United States Patent 6,143,963.

Kimata, M., and M. Negishi, 2002: Geographical distribution of proso millet, Panicum miliaceum L. on iodostarch and phenol reactions; with special references to a northern propagation route into Japanese Islands. Environmental Education Studies, Tokyo Gakugei University 12, 15-22.

Knutson, C. A., and M. J. Grove, 1994: Rapid method for estimation of amylose in maize starches. Cereal Chem. 71, 469-471.

Lágler, R., G. Gyulail, M. Humphreys, Z. Szabó, L. Horvath, A. Bittsanszky, J. Kiss, L. Holly, and L. Heszky, 2005: Morphological and molecular analysis of common millet ( $P$. miliaceum) cultivars compared to a DNA sample from the 15th century (Hungary). Euphytica 146, 77-85.

Lee, J. M., A. L. Bush, J. E. Specht, and R. C. Shoemaker, 1999: Mapping of duplicate genes in soybean. Genome 42, 829-836.

Lindeboom, N., P. R. Chang, R. T. Tyler, and R. N. Chibbar, 2005: Granule-bound starch synthase I (GBSSI) in quinoa (Chenopodium quinoa Willd.) and its relationship to amylose content. Cereal Chem. 82, 246-250.

Nelson, L. A., 1984: Technique for crossing proso millet. Crop Sci. 21, 71.

Pedersen, J. F., S. R. Bean, R. A. Graybosch, S. H. Park, and M. Tilley, 2005: Characterization of waxy grain sorghum lines in relation to granule-bound starch synthase. Euphytica 144, 151-156.

Smith, A. M., K. Denyer, and C. Martin, 1997: The synthesis of the starch granule. Annu. Rev. Plant Physiol. Plant Mol. Biol. 48, $67-87$.

Steel, R. G. D., and J. H. Torrie, 1980: Principles and Procedures of Statistics: A Biometrical Approach. McGraw-Hill, New York.

Stoddard, F. L., 2004: Starch chemistry. In: C. Wrigley, H. Corke, and C. E. Walker (eds), Encyclopedia of Grain Science, Vol. 2. 212 - 219, Elsevier Science, Amsterdam.

Wanous, M. K., 1990: Origin, taxonomy and ploidy of the millets and minor cereals. Plant Varieties and Seeds 3, 99-112.

Yamamori, M., T. Nakamura, and A. Kuroda, 1992: Variation in the content of starch-granule bound (Wx) protein among several Japanese cultivars of common wheat (Triticum aestivum L.). Euphytica 64, 215-219.

Zeller, F. J., 2000: Nutzung, Genetik und Züchtung kleinkörniger Hirsegräser: 3. Rispenhirse (Panicum miliaceum L.). J. Appl. Bot. 74, $182-186$. 